\title{
Talking Religion: Religious Diversity in Study Abroad Advising
}

\author{
Timothy Lynn Elliott \\ Brigham Young University \\ Lorien Romito \\ Babson College
}

\begin{abstract}
:
Students studying at US institutions of higher education come from a broad range of religious and non-religious traditions. Yet religion is often a "no go" topic of discussion within the American cultural context and educators frequently lack the training to engage in productive conversations about this aspect of students' identities. However, study abroad practitioners should not be reluctant to talk about religion as an important lens for cultural learning within the context of study abroad. Through careful advising and recognition of the cultural importance of faith, students from a spectrum of religious leanings can enhance their study abroad experience. This essay looks at tactics which can be used in advising three categories of undergraduate students: religious students leaving a location where their faith is in the majority and going to a place where their religion is in the minority; religious students whose faith tradition is in the majority in the place they wish to study abroad; and non-religious students who find themselves in a strongly religious community. For each of these identity groups, study abroad advisors can support students during all stages of their study abroad experience (pre, on-site and post) so students view their interaction with religion as an important portal to cultural learning in-country.
\end{abstract}

\section{Another Lens into Cultural Exploration and Identity Development: Faith and Study Abroad}

Religion is an important element in the lives of many students in the United States who study abroad. It is likewise an important element in many of the societies where these students go to study. Even so, there is very little in the literature about how to leverage religion to enhance the study abroad experience. This essay will look at the role of faith in U.S. society in the context of international education and will provide some suggestions on how study abroad practitioners can direct students to effectively use religion to learn about their host culture.

Within the United States we are socialized to believe that religion is a taboo subject in professional and social settings. U.S. religious culture generally encourages privacy and restraint, thus many of us feel uncomfortable discussing the topic and lack the vocabulary to have an effective or appropriate conversation around faith. Additionally, according to the Pew Research Center on Religion and Public Life in 2014, 70.6 percent of the U.S. population identifies as Christian, 22.8 percent do not affiliate with any particular religion and only 5.9 percent of the U.S. population represent non-Christian faiths (Pew, 2014). Thus, while we have wide diversity within Christianity, by nature of the make-up of our population, we have little opportunity for exposure to religious diversity as part of our daily lives. 
As higher education and study abroad administrators, we are trained to encourage cultural exploration and identity development for our students, and we ask them to embark on intercultural inquiry while they are abroad. While faith traditions can be an important window into intercultural understanding, especially in a new context, the societal messages we receive in the United States around religious privacy and restraint frequently dissuade us from including this important topic in study abroad advising sessions, pre-departure orientation and/or on-site orientations. Simultaneously, students may be reluctant to discuss their faith tradition with study abroad professionals both for fear of judgement or because they fail to see how this aspect of their identity will contribute to their overall experience in a new cultural context.

\section{Linking Intercultural Development and Faith Inquiry}

In order to adjust our tendency to sideline religion as an import aspect of cultural learning, it is helpful to look at the relevant definitions. The Center for Advanced Research on Language Acquisition at the University of Minnesota defines culture as, "the shared patterns of behaviors and interactions, cognitive constructs, and affective understanding that are learned through a process of socialization. These shared patterns identify the members of a culture group while also distinguishing those of another group" (University of Minnesota, 2017). Religion is the "body of persons adhering to a particular set of beliefs and practices" (Dictionary, 2017). The definitions for culture and religion have similar foci on the values or beliefs that unite a community. They also illuminate the importance of utilizing faith as an important dimension when exploring the host country culture and one's own identity.

In exploring terminology further, initiatives such as religious literacy or religious pluralism encourage education abroad advisors and students to embrace religious dialog. Further defined, religious literacy is "the knowledge of, and ability to understand religion. The importance of being religiously literate is increasing as globalization has created greater links and migration between societies of different faiths and cultures" (Rosenblith \& Bailey, 2007, 93). Religious pluralism is "a world characterized by respect for people's diverse religious and non-religious identities, mutually inspiring relationships between people of different backgrounds, and common action for the common good" (Interfaith, 2017). Both concepts frame religious inquiry as important. It provides for knowledge acquisition when operating in a global world; exploration of diverse traditions; and displays of respect. These philosophies shift conversations from themes of dogma or ideology to important competencies that promote intercultural development and reflection of one's own faith identity.

\section{Religion in a Global Context}

Another important consideration for study abroad practitioners and their students is religion in a global context. A Pew Research Center survey conducted in 2002 called The Global Attitudes, showed that wealthier countries place less importance on religion than poorer countries, with the exception of the United States. For example, fifty-nine percent of U.S. citizens say that religion plays a very important role in their lives. This is in contrast to other developed countries where the majority of our students choose to study abroad. In the United Kingdom, 33 percent of those surveyed said that religion was very important in their lives. In Italy and France, this statistic decreases to 27 percent and 11 percent, respectively (Pew, 2014). In less developed countries, the percentage of citizens who view religion as very important in their lives dramatically increases. For 
example, for Brazilians, religion plays an important role in the lives of 77 percent of its citizens surveyed and 84 percent in Ghana. While more current statistics would be helpful in further analysis of a particular country, the overall trends from the Global Attitudes study are helpful for study abroad advisors and students in recognizing patterns. U.S. students may be more religious than their host communities in Western Europe and may be less religious than those living in developing countries. These differences may be evident during their time abroad in ways that our students do not expect without proper preparation.

\section{How is religion treated in the education abroad literature?}

There is a plethora of literature on preparing students to go abroad. While this literature covers intercultural adaptation from different angles, very little of it discusses faith, either in preparing students to go abroad or in helping students use religion as a window into the local culture. As an example, the third edition of NAFSA's Guide to Education Abroad for Advisors and Administrators features a short discussion on the role religion plays in students' decisions if and where to study abroad (Brockington et al., 2005, 223, 237-8). However, there is no discussion on how advisors can help students use their own religious identity to deepen the intercultural experience of their host country or to learn more about a faith tradition different from their own. By the fourth edition of the book, even these short references to religion are no longer included (Hernandez et al., 2014). This example provides us insight into a more general observation that our field lacks in-depth research or practical resources for study abroad advisors around the connection between religion and study abroad as it relates to intercultural learning and identity development. Literature that does exit tends to be generic and revolves around two general themes: attend a service for one time cultural insight and withhold judgement of others' beliefs.

Robert Gordon summarizes the first theme: "[a]ttending religious services of all kinds is another way to meet people and get a feel for the area" (Gordon, 2010, 131). He is not alone in this sentiment. Several other writers make this suggestion, though the reason for attending local religious services vary depending on the author's viewpoint. Gordon makes his argument from an anthropological point of view. Others also argue that church attendance is a good way to learn culture (Duke, 2014, 82-4), or that attending a local church can help students maintain their spirituality (Paige et al., 2006, 78).

The second common theme evident in study abroad literature, which usually does not refer specifically to religion but rather to learned values systems or biases, is that students should be nonjudgmental and humble in their approach to cultural learning. We could call this the "thou shalt not proselyte" theme. All students will take their own biases with them when they go abroad, of course, and may be tempted to judge the new culture according to these. Religious beliefs, along with political, economic, and societal views will inform these biases and students may feel the need to proselyte on these topics. An example of the warning of doing this is McCallon and Holmes who suggest that understanding a new culture requires one to set aside preconceived notions. "What helps to develop intercultural competence is an open mind and willingness to lose the judgmental baggage that can't come with it." (McCallon \& Holmes, 2010, 139).

While discussions on religion in study abroad texts tend to be short, or non-existent, one exception is the chapter on religion in Carol Madison Graham's Coping with Anti-Americanism: A 
Guide to Getting the Most Out of Studying Abroad. In this chapter, Madison gives a long discussion of the foreign (mostly European) understanding, and often misunderstanding, of the role of religion in U.S. society. She makes the point that Americans need to be prepared to explain the unique religious culture of America and especially of the American South. (Graham, 2011, 47-70) While her specific arguments about foreign understanding of the South may not be that useful for all advisors, her broader point, that those outside the U.S. may have difficulty understanding the role of religion in America, is a good one to keep in mind when advising students. But there is more that advisors can do to support faith inquiry as a lens for cultural exploration and identity development amongst our students than just warn them of possible misunderstandings.

\section{How Can We Use Religion in Our Advising?}

Given this relative lack of research or resources on the topic of religion and study abroad, how then should study abroad practitioners approach the subject when advising prospective students?

The first step would be to gauge how a student identifies with religion. This could be done during an advising session or in a pre-advising questionnaire that asks students to outline their goals and identify aspects of their identity that will be important to them while they are abroad. Questions might include:

- Are you religious? Do you identify with a particular faith? If so, have you given any thought to how this particular aspect of your identity will have salience while abroad?

- Will you practice your religion while abroad? Have you considered contacting local faith groups?

- Regardless of your faith tradition, have you considered attending local church services as a way to learn more about the local culture?

To give some idea on how students can be advised, let us consider three types of students that may emerge from these questions. We recognize that not all students will fall into these three categories but it does provide us with a general framework so advisors can feel more prepared.

Consider first, the devoutly religious student who comes from U.S. communities where their faith is in the majority (or at least a strong minority) and who goes to a new location where they are a religious minority. This could be a Protestant student going to a predominately Catholic country, for instance, or a Christian student of any denomination going to a Muslim, Buddhist or Hindu community. For a student like this, who has strong beliefs, there may be a tendency to pre-judge local religions. Moreover, many Americans grow up with the idea that religions compete in the marketplace of ideas. However, in many places in the world religious plurality is not well accepted and so devout students need to be aware of this. Students in this category would be well advised to remember, "[g]oing abroad should expose one to new ideas and feelings, which are often inconsistent with those already held. Here the key is humility." (Gordon, 2010, 183). In some cases, not having access to their own faith community can also be a challenge to devout students and so it would help prepare them to be abroad if they know the challenges they are likely to face in not having a familiar church setting (McCallon \& Holmes, 2010, 138). 
Religiously devout students, however, may have advantages in learning the culture of a strongly religious community. Students who come from a strongly religious background or a community in which religion is often discussed are often more comfortable with discussing religion and spiritual issues with the community members they meet. As long as they approach the new community with humility and in a non-confrontational way, these students can be better prepared to learn about the local religion and, in turn, the local culture.

A second group of students are those who, in addition to learning the subject matter of their study abroad program, also hope to explore or deepen their own faith tradition while abroad. Since the study abroad experience supports cultural exploration and identity development, this should be an obvious advantage for students in this category. However, without proper coaching, preparation and advising about how to be intentional about faith exploration in their new environment, this could be a missed opportunity. This approach, though, gives students a quick way to meet locals and since they share the religious beliefs in common with their hosts, they have a base on which to build and discover aspects of the local culture. (A student testimonial from Babson College highlights this type of experience, https://drive.google.com/open?id=1e71EqH1kaIdraYt3paH4oUZN6pQIf7E-).

Brigham Young University actively follows this strategy by placing students with local congregations, and this has been a very effective tool to get Island-program students off of the islands and into the community. Faith based schools can more easily facilitate these relationships, of course, but even at secular schools, individual students can tie in with local faith communities. (For one example, see the student testimonial at http://duabroad.com/2012/08/01/exploring-faithabroad/).

A third type of student is one who does not identify with any particular religion, is atheist or agnostic. If this student chooses to study abroad in Western Europe, for example, this may not be an important identity that surfaces during their time abroad, given the statistics referenced by Pew Research Center on Religion and Public Life. However, should this student choose to study abroad in a country where religion is central to a community's way of life, this could surface as a very salient aspect of his/her identity and strongly impact the way in which s/he engages with and learns from the local culture. Without proper preparation, this difference in belief systems could be jarring for the study abroad student and/or the host community. Depending on the cultural competency of the student, this could be an excellent learning opportunity or a problematic clash. The role of the study abroad advisor could be extremely influential in guiding a student to navigate successfully this interesting difference. This type of student may also be less versed in talking about religion and might benefit from developing language that would allow them to engage respectfully with their host community.

\section{Conclusion}

We are not suggesting that study abroad practitioners be experts when it comes to discussing religion. Advisors can encourage students to do research on their own and to connect with local chaplains or faith services on campus. However, advisors can and should incorporate the following best practices when advising students:

Remember, religion is an important aspect of culture and, as such, students should 
1. Respect local religions.

2. Know the local laws in regard to religion, especially as this relates to other aspects of a students' identity. Religion may influence a society's beliefs around gender or sexual orientation and a study abroad student should be very clear about how this might influence their safety, sense of acceptance or overall experience while abroad. Students should not be judgmental about the local religion, instead they should try to understand how faith influences their daily lives, why they worship as they do, why they believe as they do. Students do not have to accept the local religion, but can gain a deeper understanding of the local culture while exploring their own relationship with faith.

3. Be wise about how one discusses religion. Students may find that in the developed world, religion is not a prevalent influencer of contemporary culture in the local community and so students might gain more by discussing other topics. However, in the developing world, religion may be much more central to the host culture and so students should not be as afraid to inquire about the local religion as long as it is done with respect.

4. Encourage students to use the local religion as a way to understand the local community.

a. Students can be encouraged to join one of the local faith communities. This may initiate friendships and be a catalyst for students to learn more about their own faith as they see it practiced in a new culture.

b. Even for those who do not join a local faith community, encourage them to attend local worship services as these can provide insight into the local community.

c. Encourage students to blend in as much as possible in the religious services by wearing appropriate attire, showing proper respect to icons, etc. If they do not know what is appropriate, encourage them to ask.

5. In general, teach students that all of the knowledge, attitude and skills they use for success in study abroad can be applied when navigating new religious communities or faith traditions.
a. Be tolerant.
b. Withhold judgement.
c. Be curious.
d. Be respectful.

\section{Bibliography}

Brockington, J. L., Hoffa, W. W. \& Martin, P. C., NAFSA's Guide to Education Abroad for Advisors and Administrators. 3rd Ed., Washington D.C.: NAFSA: Association of International Educator, 2005.

Cushner, Kenneth, Beyond Tourism: A Practical Guide to Meaningful Educational Travel. Lanham, MD: Scarecrow Education, 2004

Dictionary.com Unabridged. Random House, Inc. 15 Jun. 2017. www.dictionary.com/browse/religion.

Duke, Steven T., Preparing to Study Abroad: Learning to Cross Cultures. Sterling, VA: Stylus Publishing, 2014.

Gordon, Robert, Going Abroad; Traveling Like an Anthropologist. Boulder, CO: Paradigm Publishers, 2010 . 
Graham, Carol Madison, Coping with Anti-Americanism: A Guide to Getting the Most Out of Studying Abroad. Washington DC: Potomac Books, 2011.

Hernandez, M., Wiedenhoeft, M. \& Vick, D., NAFSA's Guide to Education Abroad for Advisors and Administrators. 4th Ed., Washington DC: NAFSA: Association of International Educator, 2014.

Interfaith Youth Core. www.ifyc.org/about. Accessed 14 April 2017.

Lantis, J. S., \& DuPlaga, J., The Global Classroom: An Essential Guide to Study Abroad. Boulder, CO: Paradigm Press, 2010.

McCallon, M. \& Holmes, B., Faculty-led 360; Guide to Successful Study Abroad. Charleston, IL: Agapy LLC, 2010.

Paige, M., Cohen, A. D., Kappler, B., Chi, J. C., \& Lassegard, J. P., Maximizing Study Abroad: A Student's Guide to Strategies for Language and Culture Learning and Use. $2^{\text {nd }}$ Ed., Minneapolis, MN: University of Minnesota, 2006.

Pew Research Center on Religion and Public Life. Religious Landscape Study, 2014, www.pewforum.org/religious-landscape-study/\#geography. Accessed 14 Apr. 2017.

Rosenblith, S. \& Bailey, B., "Comprehensive Religious Studies in Public Education: Educating for a Religiously Literate Society", Educational Studies: Journal of the American Educational Studies Association, 42/2 (Sep 2007), 93-111.

Savicki, V., Adams, I., Wilde, A., \& Binder, F., "Intercultural Development: Topics and Sequences," Frontiers: The Interdisciplinary Journal of Study Abroad 15 (Winter 2007-2008), 111-126.

Skelly, James M., "Fostering Engagement: The Role of International Education in the Development of Global Civil Society," in The Handbook of Practice and Research in Study Abroad (pp 21-32), ed. Ross Lewin. New York, NY: Routledge, 2009.

Spencer, S. \& Tuma, K., The Guide to Successful Short-term Programs Abroad $2^{\text {nd }}$ Ed., Washington DC: NAFSA: Association of International Educator, 2007.

University of Minnesota. Center for Advanced Research on Learning Acquisition (CARLA). carla.umn.edu/culture/definitions.html. Accessed 15 June 2017.

Warner, C. M. \& Walker, S. G., "Thinking about the Role of Religion in Foreign Policy: A Framework for Analysis," Foreign Policy Analysis 7 (2011), 113-135. 